\title{
POLYSEMIC INTERACTIONS OF ETHNOMATHEMATICS: AN OVERVIEW
}

\author{
INTERAÇÕES POLISSÊMICAS DA ETNOMATEMÁTICA: \\ UMA VISÃO GERAL
}

\section{LAS INTERACCIONES POLISÉMICAS DE LA ETNOMATEMATICA: UNA VISIÓN GENERAL}

\section{Milton Rosa ${ }^{1}$ \\ Daniel Clark Orey ${ }^{2}$}

\begin{abstract}
Local knowledge interrelationships related to assorted academic knowledge areas are important to enable a more precise understanding about a particular study field in relation to diverse forms of mathematics. Here, in this article, interrelations are addressed, especially wherever one needs to understand specific concepts acquired in academic knowledge broadly-based on science and mathematics; which may be supported by research fields called ethnoscience or ethnomathematics. This theoretical article essentially considers the emergence of important terminologies connected to certain research areas referred as ethno-x. By means of a bibliographic study, the central theme of ethno-x presents us with an attempt to understand polysemical relations that emphasize the ethno in the sciences. The main goal in this discussion is to further advance research and understanding in relation to an ethnomathematics research program and its polysemic relation with other knowledge fields.
\end{abstract}

KEYWORDS: Ethnoscience. Ethnomathematics. Ethno-x. Interactions. Polysemy.

\section{RESUMO}

O inter-relacionamento de saberes locais com as diversas áreas de conhecimento é muito importante para que possamos obter informações mais precisas sobre um determinado campo de estudo. Para que tenhamos condições de abordar com clareza essas inter-relações, necessitamos compreender os conceitos específicos encontrados em grandes áreas do conhecimento acadêmico como as Ciências e a Matemática, que podem estar respaldadas por outros campos de pesquisas denominados etnociências e etnomatemática. Nesse artigo teórico, julgamos necessário discutir o surgimento de algumas terminologias importantes com relação a determinadas áreas de pesquisa denominadas etno- $x$, pautando-nos em um estudo bibliográfico que tem, como temática central, a tentativa de compreender a polissemia de significados para o termo etno para ressaltarmos o nosso objetivo principal que é avançarmos nos estudos e compreensões da etnomatemática como um programa de pesquisa e a sua relação polissêmica com outros campos do conhecimento.

PALAVRAS-CHAVE: Etnociências. Etnomatemática. Etno-x. Interações. Polissemia.

\footnotetext{
${ }^{1}$ Doutor em Educação, Liderança Educacional em Gestão Educacional da Educação Básica - Califórnia State University (CSU) - Sacramento, CA (EUA). Professor Adjunto - Departamento de Educação Matemática (DEEMA) e professor de Educação Aberta e a Distância (CEAD) - Universidade Federal de Ouro Preto (UFOP) Ouro Preto, MG - Brasil. E-mail: milrosa@hotmail.com ${ }^{2}$ Doutor em Education - The University of New México, Estados Unidos (UNM) - Albuquerque, NM - EUA. Professor Adjunto - CEAD - Centro de Educação Aberta e a Distância - Universidade Federal de Ouro Preto, (UFOP - CEAD) - Campus Universitário Morro do Cruzeiro - Ouro Preto, MG - Brasil. E-mail: oreydc@gmail.com
}

Received on: 25/02/2017 - Accepted on: 24/05/2017

(C) ETD-Educação Temática Digital Campinas, SP $\quad$ v.19 $\quad$ n.3 $\quad$ p. 589-621 jul./set. 2017




\section{RESUMEN}

La interrelación del conocimiento local está relacionada con áreas del conocimiento académico variadas y es importante para permitir una comprensión más precisa acerca de un campo de estudio particular. Aquí, estas interrelaciones se abordan claramente, especialmente donde se necesita entender los conceptos específicos adquiridos en el conocimiento académico ampliamente basado en las ciencias y las matemáticas; los cuales pueden ser fundamentados por otros campos de investigación llamados etnociencia y etnomatemática. Este artículo teórico considera esencialmente la aparición de importantes terminologías asociadas con ciertas áreas de investigación denominadas etno-x. Orientado hacia un estudio bibliográfico, el tema central de etno-x consiste en un intento de comprender las relaciones polisémicas para los términos de hecho hacen hincapié en lo etno. El objetivo principal de esta discusión es avanzar en la investigación y la comprensión del contexto del programa de investigación de etnomatemáticas y sus relaciones polisémicas con otros campos del conocimiento.

PALABRAS CLAVE: Etnociencias. Etnomatemáticas. Etno-X. Interacciones. Polisemia.

\section{INTRODUCTION}

Interrelations between local knowledge forms with diverse knowledge areas are important in order to obtain information about a particular subject of interest. A precise approach to these interrelations helps us to understand specific concepts found in specific areas of academic knowledge such as biology, ecology, and mathematics, which are supported by recent research fields of ethnobiology, ethnoecology, and ethnomathematics. Therefore, in the context of the emergence of important terminologies related to research fields we use the term: ethno-x.

In regards to ethnoscience, it is important to start this discussion using a generic term, in which $x$ refers to a particular discipline or study field that belongs to methodological classifications of academic knowledge while ethno refers to the members of distinct cultural groups who are identified by means of their own traditions, codes of conduct, symbols, and myths as well as by their different ways of reasoning and inferring (D'AMBROSIO, 1985). Hence, the prefix ethno is considered polysemic since it acquires a more comprehensive concept than the definition of ethnicity.

In its origins, investigations related to ethno-x knowledge fields emphasized linguistic and taxonomic aspects that have often relegated the diversity and dynamics of the relations of the members of a given culture to the background along with the context and natural environment in which they are found (D'OLNE CAMPOS, 2002). According to this context, the term ethno-x carries a certain mark of ethnocentrism in which the meaning of the prefix ethno is attached to Western scientific fields and value systems that might be interpreted or intended to subordinate or shape others' knowledge into Western scientific categories (D'OLNE CAMPOS, 2002).
(C) ETD- Educação Temática Digital
Campinas, SP
v.19
n.3
p. $589-621$
jul./set. 2017 
However, this mark can be attenuated with the use of a science $x$ that can be redefined, recovered, and revitalized through the emergence of new knowledge fields such as ethnobiology, ethnoastronomy, and ethnomathematics. In this regard, D'Olne Campos (2002) argue that it is necessary to expand and reconstitute the conceptualization and meaning of ethno-x. Consequently, it is possible to detach it from its ethnocentric character by recovering the comprehension of the dynamics of humanity's relation with nature in order to situate it in the field of ethnography of knowledge, techniques, and methodologies.

Thus, when researchers come into contact with members of other cultural groups, there is a need for them to adopt a new and open mind, leaving prior classifications of the culture of their origin behind as much as possible, so that they can develop a deeper understanding of the existence of other classification systems and forms of knowledge. In this way, it is important that the ethno prefix be devoid of prejudices associated with one's own cultural origin (bias) so that the ways of doing by ethno-x by others can be perceived as scientific and mathematical knowledge according to their own ethnos.

According to D'Olne Campos (2002), it is important to emphasize that it is through ethnographic work that forms of ethno-x emerge. When we are in the field, it is disarmed through the adoption of an ethnography of knowledge, techniques and practices, without trying to recognize in others the disciplines that only exist in Western academic/school contexts.

\section{THE HISTORICAL COMPILATION OF ETHNO-X KNOWLEDGE}

It is impossible to attempt to locate in time and space the first time in which both interests and concerns were expressed in regards to the scientific expertise developed by members of other cultures. This interest has long manifested itself in exploration and trade, the earliest contacts, and through isolated and less systematized situations, which began to be observed and reported when individuals traveled to different regions of the world. Thus, gaining recognition of the history of ethno-x knowledge fields and their precursory approaches helps to understand the appropriation of actions developed in different study areas.

In these travels, it was necessary for individuals to communicate with members of local cultures. In early cultural interactions, individuals observed customs and related scientific knowledge, as well as the culture of the people they encountered, and recording their observations. In early notes and records, they recognized that there were different mathematical procedures and scientific practices (ROSA; OREY, 2005). Subsequently, these individuals began to write about the scientific knowledge developed by other peoples.
(C) ETD-Educação Temática Digital
Campinas, SP
v.19
n.3
p. $589-621$
jul./set. 2017 
From its origin, humans have accumulated scientific knowledge in relation to their own natural, social, cultural, political, economic, and environmental contexts; science as we understand it currently, has emerged as a distinct way to explain, understand, and deal with these environments. In this way, all people have developed scientific knowledge and methods of problem solving that work satisfactorily in their sociocultural context, often successfully for thousands of years before contact with European colonizers. According to D'Ambrosio (2001), diverse forms of thinking and doing occurred through specific motivations and interests, which are subject to the changes resulting from the exposure of the members of these groups to other cultures.

For example, from the fifteenth century onwards, though the great navigations, Europeans (colonizers) began to be interested, in an often prejudicial and unsystematic way, of the scientific knowledge developed by subjugated (colonized) peoples they encountered (ROSA; OREY, 2005). In this often violent cultural dynamic, the colonizers' knowledge was absorbed and appropriated by the colonized. However, this same knowledge absorption did not always occur easily, and often was the cause for transformation of the knowledge of the colonizers as well. In this way, knowledge acquired over time was modified and retained often unique aspects or remnants of local or indigenous knowledge.

The knowledge of the colonizers was transformed through contact as well, since elements of the knowledge of the colonized were incorporated and enriched the knowledge of the colonizers. Thus, the pharmacopoeia ${ }^{3}$, cooking, language, music, the arts, mathematics, and religion itself are evidence of this cultural dynamic (D'AMBROSIO, 2001). In other words, this cultural dynamism promoted the recognition of different kinds of scientific knowledge that began to be perceived between the contact of the colonizers and with the colonized who were set in different cultural environments and contexts than what they were accustomed.

Thus, as a result of these cultural encounters (both good and bad) between conquerors and the conquered, new forms of knowledge were gradually developed and changed over time. Although many conquered people had developed a pre-conquest scientific knowledge, the use of historiography of science has not been sufficient to aid in the recognition of cultural dynamism of many of these initial encounters. The religions, art, knowledge, and scientific paradigms originating in Europe have continued to be transmitted

\footnotetext{
${ }^{3}$ Pharmacopoeia, pharmacopeia, or pharmacopoeia (literally, drug-making), in its modern technical sense, is a book containing directions for the identification of compound medicines, and published by the authority of a government or a medical or pharmaceutical society.
}

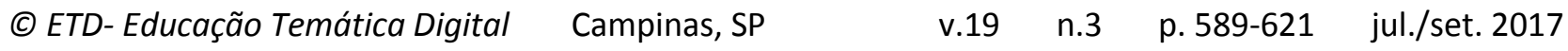


and influenced diverse cultural groups that inhabit former colonies located in the Americas, Africa, Asia, and the Pacific (ROSA; OREY, 2005).

In general, at the beginning of the nineteenth century, this historical context enabled the early development of ethnoscience (ARGUETA, 1997). For example, Augustin Pyramus De Candolle, a Swiss naturalist and botanist conducted, in France, the first studies about relations between plants and human species. These studies related to the classification of plants were grouped in a book entitled Elementary Theory of Botany, written in 1813 by De Candolle. This series of development of the ethno-scientific knowledge continued with the publication in 1819 of the second edition of this book, entitled Applied Botany, which included agricultural, medicinal, economic, and industrial botany.

In 1874, the term Aboriginal Botany was coined by Stephen Powers. He defined it as the study of the utilization of plants by Western societies as well as the study of the types of vegetation native people use such as medicine, food, textiles, and ornaments (VIZGIRDAS, REY-VISGIRDAS, 2006). Yet, most Western missionaries, scientists, and researchers considered the native people primitive because they did not develop a botanical/scientific knowledge comparable to that accumulated by a civilized society. Thus, as part of the conquest ethos, much of the knowledge that members of native societies had developed throughout generations was despised and essentially disregarded (CLEMENT, 1998a).

The science that began to be organized in the late nineteenth century went hand in hand with the process of devaluation of most that was non-European-based. That which was found or produced outside of Western academia was used to (re)affirm colonial power and the overall hegemony by using the scientifically produced knowledge from the colonizers. In 1879, the term ethnographic botany was coined by Alphonse Tremeau Rochebrune, who defined it as the study of plants in archaeological sites, and which provided valuable information on the diet, hygiene, and industry of non-Western and soon to be extinct cultures (WICKENS, 1990).

In the following decade, in 1889, Robert Eduard Carter Stearns coined the term ethnomalacology or ethnoconquiliology, which is the study of the interactions of mollusks with humans and the environment. Although the ethno prefix was used by Stearns, the emphasis of his study was directed only at malacology (CLEMENT, 1998b). In 1896, in the United States, Harshberger was the first botanist to use the term ethnobotany in academic circles and define it as the study of the relation between native peoples and plants as well as the uses of these plant materials by diverse peoples (SCHULTES; REIS, 1995). 
Early studies in ethnobotany have assisted in elucidating the cultural position of how diverse indigenous people use plant-based materials for food, shelter, and clothing. These studies provided important information on the distribution of plants and assisted investigators in the discovery of old trade routes, and suggested new manufacturing lines (CLÉMENT, 1998a). Currently, ethnobotany covers the study of the interrelations between societies and nature (ALCORN, 1995) through a structured approach based on methodologies that study indigenous cultures and people.

Thus, some thematic perspectives emerged from this approach (XOLOCOTZI, 1985), which later gave rise to new questions about native, traditional, and popular knowledge systems (HVIDING, 2001). Early work in these knowledge areas that are now known as ethno were developed by the first pioneers in the field and originated new research subareas such as ethnozoology, which was coined by Otis Tufton Mason in 1899. He defined it as the study of the fauna of a certain region according to the knowledge acquired by the members of distinct cultural group who live in the same environment (SANTOS-FITA; COSTA-NETO, 2007).

In the literature, the term ethnozoology only appeared in academic circles in an article entitled Ethnozoology of the Tewa Indians written by Henderson and Harring in 1914. Two years later, in 1916, the term ethnogeography was a term coined by John Peabody Harrington in a book entitled The Ethnogeography of the Tewa Indians. Ethnogeography has come to be considered as the knowledge area that studies the members of cultural groups and their adaptation to social, cultural, and natural environments in which they are inserted.

In 1930, the term ethnohistory was used for the first time by Fritz Röck and his study group named Viennese Study Group for African Culture History (WERNHART, 1987). After almost two decades of oblivion, ethnohistory reemerged in the United States in the 1950s and it was considered an interdisciplinary study and research area with an emphasis centered on the use of history and ethnology. Nowadays, ethnohistory can also be understood as an ethnographic study of cultures and the native customs of diverse cultural groups.

In 1935, the term ethnobiology was coined by Edward F. Castetter while conducting research on the knowledge and use of the environment by non-Western peoples (CLEMENT, 1990b). This knowledge field emerged from the areas of sociolinguistics, cognitive anthropology, and ethnoscience as a field of multidisciplinary research that investigates the diverse cultural perceptions of humanity's relation to nature. It also investigated ways in which perceptions are ordered and classified by societies through language (BEGOSSI, 1993).

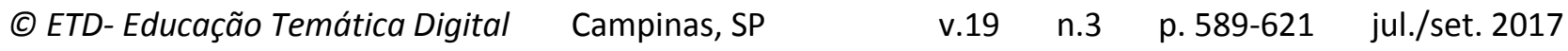


In the following decades, many of these academic knowledge areas continued to produce new study sub-areas or ethno-xs. For example, ethnoherpetology was a term coined by Frank Goldsmith Speck in 1946, which sought to examine the relation and coexistence of the members of distinct cultural groups with the reptiles. He considered it as a form of herpetological science looking at how the relation was developed by members of distinct cultural groups and it may have been based on the parameters of Western science (COSTA-NETO, 2000). Thus, there may be a symbiosis between these two types of knowledge, which seeks to integrate practical aspects of herpetology developed by the members of these groups with the scientific aspects provided by the academy.

Ethnoentomology is a term coined in 1952 by Lelan Clifton Wyman and Flora L. Bailey, who defined it as the study of the interaction of members of distinct cultural groups with insects as well as their use in societies. In 1957, the term Ethnomycology was first coined by Robert Gordon Wassom and Valentine Pavlova Wassonin the book Mushrooms, Russia, and History; which contains useful information on the culture and history of wild fungi (BOA, 2004). Ethnomycology has come to investigate the interactions between fungi and humans through the study of traditions, myths, and practices present in the daily life of members of distinct cultural groups (WASSON, 1980).

In 1954 the term ethnoecology was first used by Harold Conklin to study the relationship between members of particular cultural groups with their natural environment, including the plants, animals, soil types, and access to water in order to seek the essential balance for this coexistence. The study conducted by Conklin (1954) emphasized the recognition of the influence of the natural environment on the relationship between members of distinct cultural groups and the environment.

The results of his work have contributed and changed the investigative focuses of the research by directing them towards the understanding of this relation according to the point of view of natives and local communities. It originated as an extension of ethnoecology from a purely cognitive perspective to the recognition of the influence of the historical and political contexts in the development of ideas, procedures, and practices present in the natural, social and cultural (NAZAREA, 1999).

In 1967, ethnoictiology was a term used in academic circles for the first time by W. T. Morrill, who sought to understand the phenomenon of interaction between humans and fish by studying the cognitive and behavioral aspects of this relation (MARQUES, 1995). In this direction, ethnoictiology can be considered as the study of the relations of fish in a

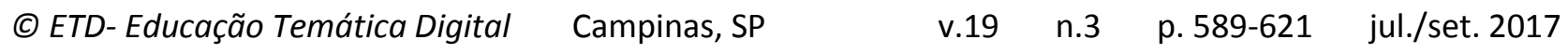


given culture (POSEY, 1987). Probably, in this same year, the term ethnopharmacology first appeared in the academic circles in the report written by Efron, Holmstedt, and Kline entitled Ethnopharmacological Search for Psychoactive Drugs.

However, the termalization of this term only occurred in 1979 with the creation of the Journal of Ehnopharmacololgy (ALMEIDA, 2003). It is a field of knowledge that can be considered as the study of the medical practices developed by the members of distinct cultural groups and their scientific relation with the drugs used in the medical academic systems (ELIZABETSKY, 2000).

In 1969, the term ethnoornithology was used by Allen R. Maxwell who studied the cognitive, behavioral, and symbolic relations between the human species and birds. However, this field of scientific knowledge may have arisen as early as 1884 in the United States with studies conducted by Wells W. Cooke on native knowledge about birds. There is argument that the term ethnoornithology was first published in the book Bird Nomenclature and Song interpretation of the Canadian Delaware: An Essay in Ethno-ornithology written by the American anthropologist Frank G. Speck in 1946 (FARIAS; ALVES, 2006).

In 1970, the term ethnophilosophy was first used in academia in an essay published by Paulin Hountondji entitled Comments on Contemporary African Philosophy to designate the beliefs developed by members of numerous African cultural groups. Ethnophilosophy refers to the set of beliefs and knowledge manifested in the thoughts and actions of individuals who share a particular culture. In 1971, the term ethnomineralogy was coined by Dean E. Arnold and it is considered as the study of the interrelationship between the members of distinct cultural groups, minerals, and inorganic resources that occurs in their own sociocultural environment.

In 1973, the term ethnoastronomy was first used by Elizabeth Chesley Baity and it was defined as the science that studies astronomical knowledge through the investigation of the customs developed by the members of a given culture (Mourão, 1995). It also investigates the relation between the members of distinct cultures and the development of astronomical knowledge in the general context of these cultures (IWANISZEWSKI, 1991). In 1977 , the term ethnolinguistics was introduced in the academic by Giles, Bourhis, and Taylor who defined it as the linguistic behavior of peoples in their own sociocultural context. It is designated as the study of the relationship between languages and cultures.

In 1981, the term ethnoagronomy was first used by Emilio Moran and it was defined as the study of existing relations between the members of distinct cultural groups and the

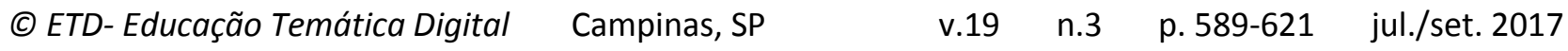


soil by comparing the pedological ${ }^{4}$ knowledge developed by caboclos ${ }^{5}$ of Pará, in the North region of Brazil, with those brought by new colonists from the southern part of Brazil, during the implantation of agricultural settlements in the Amazon area. Through chemical laboratory analysis, it was demonstrated that the soils of the areas chosen by the caboclos had better fertility conditions compared to the areas chosen by the new settlers (MORAN, 1981).

The term ethnopedology was introduced by Williams and Ortiz Solorio in 1981 and it can be considered as the study of the knowledge developed by native, local, and traditional peoples with respect to the soil. The results of this study showed that the ethnopedological approach contributes to the articulation and integration between academic pedological knowledge shared by researchers and investigators on soil science with the local knowledge in regards to the land and to the characteristic of rural populations such as peasants and Indigenous people.

According to this context, peasant and Indigenous populations developed their own techniques and strategies of land use that reveals the existence of local pedological knowledge, which underlies soil management practices adopted by members of these populations. This local knowledge is transmitted and diffused from generation to generation through oral language, which is associated to different worldviews (cosmologies) that permeate daily events (TOLEDO, 2000).

In 1995, the term ethnocenology, introduced by Jean-Marie Pradier who studies the practices of theatrical shows or stories developed by the members of different cultures from a non-Eurocentric analytical perspective that is attentive to the global aspect of expressive manifestations, which includes its physical, spiritual, emotional, and cognitive dimensions. Thus, the main objective of ethnocenology is the study of these ways by detaching them from the referents of Western theater because they refer in the practices and concepts developed in the cultures in which they are originated and produced.

During the first decade of the $21^{\text {st }}$ century, the term ethnocomputing was introduced in 2002 by Matti Tedre in his master's thesis entitled Ethnocomputing: A Multicultural View

\footnotetext{
${ }^{4}$ Pedological refers to the study of the formation, characteristics, and distribution of soils in their natural environment.

${ }^{5}$ Caboclo is the designation given in Brazil to the individual that were generated from the miscegenation of native-indigenousness peoples and White immigrants. This name is also used to adjectivize the individuals from the Brazilian wilderness, who have rustic and mistrusted manners.
}
(C) ETD- Educação Temática Digital
Campinas, SP
v.19
n. 3
p. 589-621
jul./set. 2017 
on Computer Science that was developed at the University of Joensuu in Finland (EGLASH, BENNETT, O'NONNELL, JENNINGS, CINTORINO; 2006). Ethnocomputing is the study of the interactions between computing and culture that emerge from the knowledge developed by the members of distinct cultural groups by means of the study of computational phenomena built up in the sociocultural environment in which these members are inserted (TEDRE, 2002).

Computational technology is influenced by cultural practices linked to the technological development of members of these groups. It is also a research field that studies computing applications in different cultural settings (ROSA; OREY, 2016). Thus, ethnocomputing offers a tool for developing a multicultural approach in computer science education as it recognizes the influence of societal and cultural background on computing technology (TEDRE, 2002). It is important to emphasize here that ethnocomputing has its roots on the assumptions of the ethnomathematics program in which a few of the early investigations in this area could be considered as the studies in ethnocomputing such as the study conducted by Ascher and Ascher (1981) on the Inca Quipus and Eglash's (1999) investigations on the African fractals (TEDRE, 2002).

In 1992, the connection between computing and culture was considered an autonomous research field of research by Anthony Petrillo in his PhD thesis entitled Responsive Evaluation of Mathematics Education in a Community of Jos, Nigeria. In 1994, Petrillo reworked the concept of ethnocomputing as a knowledge field distinct from mathematics in his study entitled Ethnocomputers in Nigerian Computer Education presented at the 1st Annual Conference of the Mathematical Association of Nigeria (ROSA; OREY, 2016).

Two decades later, by applying the concept of ethnocomputing, Eglash et al. (2006) uncovered mathematical knowledge embedded in the designs of various characteristics of both indigenous and contemporary cultures, from traditional beadwork and basket weaving to modern hairstyles and music, by developing culturally situated design tools, which are web-based software applications that allow students to create simulations of cultural artifacts $^{6}$.

\footnotetext{
${ }^{6}$ Cultural artifacts are objects created by the members of cultural groups, which give cultural clues and information about the culture of its creators and users (ROSA; OREY, 2016). They have some significance in the daily life of distinct cultural groups because "the language of the shapes, the designs, the myths, and the colors, confirm the community's sense of reality and give it control over its own time and its own space" (VOLTZ, 1982, p. 45). Therefore, these artifacts are made to adorn walls, ceilings, baskets, utensils, clothes, jewelry, and even the human body itself as well as to serve as religious purposes (ONSTAD, KASANDA; KAPENDA, 2003).
}
(C) ETD-Educação Temática Digital
Campinas, SP
v.19
n.3
p. $589-621$
jul./set. 2017 
In this context, Rosa and Orey (2016) have argued that ethnocomputing helps students to perceive their mathematical identity in order to enable them to recover their hidden computational capital by developing a series of interactive, web-based teaching tools, which capture interest and imagination in mathematics classes. In this context, the application of:

(...) ethnocomputing results in an expressive computational medium that affords new opportunities to explore the relationships between youth identity and culture, the cultural construction of mathematics and computing, and the formation of cultural and technological hybridity (EGLASH at al. 2006, p. 347).

According to this assertion it is necessary to develop real-world connections that tie into the students' cultural heritage in the process of teaching and learning mathematics. Thus, Eglash at al. (2006) claim that culturally situated design tools provide a flexible learning environment to do that, which enables students to reconfigure the relationship between cultures, mathematics, and technology because many cultural designs are based on mathematics and computing principles. This software helps students to learn these principles as they simulate the original cultural artifacts by developing their own creations.

In 2002, the term ethno/modelling was introduced by Rodney Carlos Bassanezi who argued that mathematical ideas, procedures, and practices used in daily life present alternative interpretations of reality. Thus, when mathematics is assumed as a study field whose content is present in a concrete reality, it can be considered a strategy of action or an interpretation of this reality. We are adopting what we characterize as an ethno/modelling posture (BASSANEZI, 2002).

In this approach, the use of ethnomathematical assumptions and the application of diverse tools and techniques of mathematical modelling allows us to perceive reality by using different lenses, which gives insight into the mathematics performed in a more holistic way (ROSA; OREY, 2013). When we recover the mathematical knowledge common to the local culture by means of modelling, this process is denominated ethnomodelling since the mathematical knowledge is constructed from the "cultural practices of the community" (CALDEIRA, 2007, p. 83).

Ethnomodelling can also be considered as a set of pedagogical actions developed through modelling, which is based on the sociocultural context of the members of distinct cultural groups. Thus, this context enables the exploration of locally developed mathematical knowledge through the appreciation and respect of cultural values as well as the knowledge acquired by practices experienced in sociocultural environments.

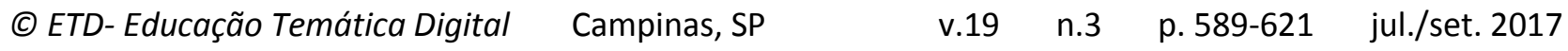


It is important to share here Caldeira's (2007) point of view that affirms that mathematical knowledge is inherent to the reality of members of distinct cultural groups as it establishes itself as an important tool for the interpretation of everyday phenomena, as well as to make possible the decision-making process in regards to this reality. For example, studies conducted D'Ambrosio (1993), Rosa (2000), and Rosa and Orey (2003) show that ethnomathematics contextualizes the mathematical knowledge developed by members of distinct cultural groups in order to humanize academic mathematics through modelling.

Ethnomathematics perspectives strengthen mathematical modelling. In more recent studies, ethnomodelling has been described as the study of mathematical phenomena that occur in particular cultures; it is a social construct that is culturally rooted, and contemplates cultural aspects of mathematical knowledge that arise during the modelling process (ROSA; OREY, 2010). Therefore, modelling provides a valuable pedagogical approach suitable for an ethnomathematics program because it contextualizes mathematical knowledge developed locally (ROSA; OREY, 2016). Hence, ethnomodelling is the study of mathematical phenomena that occurs in diverse cultural contexts, where these phenomena are socially rooted constructs that include cultural aspects of mathematical knowledge in the modelling process.

Ethnomodelling is the elaboration process of problems and questions that have arisen from practical contexts and form an image or sense of idealized versions of mathema, which are the actions for explaining and understanding daily phenomena in order to survive. This perspective constitutes a critical analysis of knowledge generation and production (creativity) that enable to discuss the social mechanisms of the institutionalization of knowledge (academics), and its transmission through generations (education) (ROSA; OREY, 2010).

Ethnomodelling presents a set of educational opportunities developed through the modelling process conducted in sociocultural contexts. Such contexts allow for critical exploration of local mathematical knowledge by appreciating and respecting cultural values developed by members of distinct cultural groups. This stance indicates that mathematical knowledge is inherent to the reality of these members. This knowledge establishes itself as a tool for the decision-making process regarding their unique perspective and reality (ROSA; OREY, 2013).

This holistic context allows students to engage in the modelling process, to study reality systems in which there is support to create an understanding of interrelated aspects and components of the system studied, as well as the relations among them (D'AMBROSIO,
(C) ETD-Educação Temática Digital
Campinas, SP
v.19
n.3
p. $589-621$
jul./set. 2017 
1990). Such systems have revealed sophisticated mathematical ideas and procedures that include, for instance, the geometric principles in craftwork, architecture, or the traditional practices encountered in activities and artifacts found in local contexts.

Such mathematical practices involve numeric relations found in measuring, classification, calculation, games, divination, navigation, astronomy, modelling, and a wide variety of other mathematical procedures used in diverse cultural practices and artifacts (EGLASH at al. 2006). This context allows the development of a definition of ethnomodelling as the translation of local mathematical ideas, procedures, and practices in which the prefix ethno relates to the specific mathematical knowledge developed by the members of distinct cultural groups.

Therefore, it is necessary to start with the social context, reality, and interests of students, and not merely enforce a set of external values and decontextualized rules and curricular activities which have no meaning for them (ROSA; OREY, 2013). In this regard, the main aspect of the ethnomodelling approach is to solve problems, to develop the comprehension of alternative mathematical systems, and help students to gain a better understanding of the importance and role of mathematics in society (ARAÚJO, 2010; BARBOSA, 2006).

In concluding this historical compilation on the development of the ethno-x of the knowledge fields, we understand that, in sociocultural representations, different concepts of ethno are directed towards to the understanding and comprehension of the objects of study that constitute the ideas, procedures, and practices as well as the dimensions of space and time developed by members of distinct cultural groups. It is important to emphasize that, at this time, innovative and interrelated ethno-x knowledge fields such as ethnotransdisciplinarity, ethnopedagogy, and ethnomethodology have been developed into the ethnomathematics perspective.

\section{AN INTRODUCTION TO ETHNOSCIENCE}

Ethnoscience is rooted in the scientific proposals elaborated at the end of the 19th century, which sought to record and catalogue a wide variety of plants and animals by the members of distinct cultural groups. It is noteworthy to state that early ethnoscience texts often employed terms such as ethnobotanic and ethnozoology, which is probably a consequence of the strong relationship between ethnoscience and the fields of natural sciences that underlay it (BARRAU, 1983).
(C) ETD-Educação Temática Digital
Campinas, SP
v.19
n.3
p. $589-621$
jul./set. 2017 
However, it was only in the 1950s and 1960s that ethnoscience was established as a multidisciplinary research field based on anthropological studies related to the studies of the role of systems of knowledge and logics developed by members of different cultures (CLEMENT, 1998a). Ethnoscience is related to the relationship between humans and their environment, and it has been focused mainly on what has been named the knowledge of others. Hence, it is the "study of scientific and, by extension, technological phenomena in direct relation to their social, economic and cultural background" (D'AMBROSIO, 1987, p. 74). It also "may be taken to refer to the system of knowledge and cognition typical of a given culture" (CRUMP, 1990, p. 160).

At the end of the $19^{\text {th }}$ century, the ethnoscience focused more on the linguistic, classificatory and taxonomic aspects of given cultures with a disinterest in the dynamics and interrelations that occurred between the sciences, society and nature. There was, however, a quest or move towards a conceptualization of the ethnosciences and their multiple ethno$x s$ that were emerging. The movement proposed that the focus of these sciences be directed more towards the diversity and plurality of the dynamics of the relationships involving society and nature (D'OLNE CAMPOS, 2002).

The term ethnoscience was first used in the academic field in the index of the book entitled The Outline of Cultural Materials written in 1950 by George Peter Murdock and his collaborators Clellan, Ford, Hudson, Kennedy, Simmons, and Whiting (CLEMENT, 1998a). This book contains a numerical system used to categorize cultural data for the purpose of facilitating a conduction of the research field with an organization of cultural information accumulated in the archive named the Human Relations Area File, identified as a set of ideas about nature, and humanity, which included ethnobotany, ethnozoology, ethnometereology, and ethnophysics.

In the 1960s, the ethnosciences were characterized as a movement dedicated to the revitalization of ethnography through the study of local knowledge systems and cognitive processes that applied analytical techniques that were derived mainly from the field of structural linguistics in ethnographic research. Therefore, a particular cultural group can be represented by their own popular classifications, which may become a form of ethnoscience for this group, mainly by particular ways of classifying their material, natural, and social universe (STURTERVANT, 1964). 
For example, ethnohistory can be considered the conception that members of distinct cultural groups develop and share about past events rather than being considered only the history of, or a collection of folkloric trivia, or chronological facts. Consistent with this view, ethnobotany can be considered as a set of specific sociocultural conceptions developed by the members of distinct cultural groups about the incorporation and use of plant-based materials rather than being considered only a description of plants and their organized use with based on a binomial taxonomy.

This context allowed the ethnosciences to propose new anthropological approaches whereby cultures were not perceived only as a collection of artifacts and a set of behavioral norms, since they began to be considered as knowledge systems, which were revealed by their linguistic structures. This perspective allows us to consider knowledge as a set of skills, abilities, and competences spread throughout the generations, whose purpose is to discover principles that govern the norms of organized cultures in order to determine if these principles are universal (BROWN, 1999). In this approach, the sciences sought to focus on the ideational aspects of cultures and nature by representing an important rupture with the materialistic approaches in some fields of study such as ethnobotany.

This system of ethnological classification reflecting human behavior, social life, customs, material products, and ecological configurations allows for multiple classifications of individual objects through their forms, materials, and functions. Hence, D'Ambrosio (2000) has argued that the ethnosciences are a body of knowledge that establishes explanation systems and diverse ways of knowing and doing developed by members of diverse cultures who have accumulated it over generations in specific cultural environments.

The ethnosciences are linked to etymological questions because the ethno prefix comes from the Greek éthnos that indicates the origin and identity of sociocultural conditions of members of distinct cultures. These conditions include their beliefs, values, symbols, myths, rites, language, ideas, procedures, and practices. From this identity, experiences and concepts of ethnicity, people, social class, and nation originate, materialize, and are defined, because the term éthos is related to the customs and habits developed by the members of distinct cultural groups.

The ethnosciences help to promote logical, epistemological, and methodological revisions of the known sciences, aiming at documenting, studying, and valuing the wide and highly diverse human repertoire of problem-solving, action, knowledge, and the practices

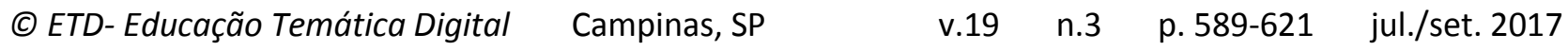


developed by members of different cultural groups across the planet. Currently, it has sought to transpose classificatory approaches since investigators have expressed interest in the study of the interrelations involving members of distinct cultural groups in their own environments.

However, it is necessary to support research agendas in the ethnosciences in order to allow both investigators and educators to perceive ethno-xs as study areas using the ethnography of knowledge, procedures, techniques, and practices without trying to recognize in other knowledge fields disciplines that only exist in the academy (D'OLNE CAMPOS, 2002). This context allows for the ethnosciences to originate a new historiography of scientific achievements, knowledge, and practices by considering culture as a set of belief systems, values, ideas, procedures, and practices developed by members of different cultural groups.

The emergence and development of ethnoscience contributed to questioning and relativizing the seeming universal rationalities of Western knowledge by creating a positive valuation approach of local knowledge. However, there is a need to emphasize how, despite its contributions to the development, the ethno adjective still maintains an implicit connotation in which the knowledge generated by others, namely the colonized and or minority groups is studied and validated from the scientific knowledge that was developed by Western cultures.

It is important that we find ways in which to understand how cultural dynamism takes place between academic and local knowledge systems. In this dynamic, the members of distinct cultural groups identify and decode local knowledge that has been acquired from generation to generation, accumulating it and transmitting it. At the same time, the contact with academic knowledge helps them establish relationships and comparisons between these two types of knowledge (ROSA, 2010). In line with this point of view, D'Ambrosio (2005) argues that communication between generations and the encounter of groups from different cultures creates a cultural dynamic because cultures are not frozen in time and space.

This dynamics has been gradual and what we perceive is a mutual exposure of cultures is a cultural subordination and sometimes the destruction of one of the cultures in confrontation or a multicultural coexistence (D'AMBROSIO, 2005). In this context, there is a complementarity of knowledge relations existing between the members of distinct cultural groups. In this regard, D'Ambrosio (2001) states that there are different ethnosciences,

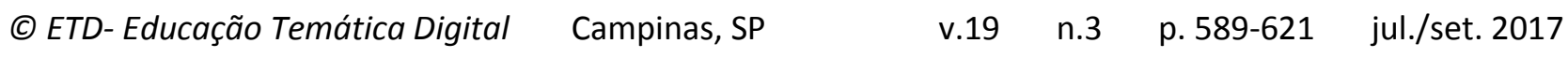


which also include the Western sciences. The mutual influences among them have helped to originate the current study of ethnomathematics.

\section{INTERACTIONS BETWEEN ETHNOMATHEMATICS, ETHNOSCIENCES, AND OTHER KNOWLEDGE FIELDS}

From an ethno-x perspective, the sciences can be understood as a collection of ways that humanity has developed for explaining, understanding, comprehending, problemsolving, and interacting with unique cultural and natural environments. The members of distinct cultural groups have learned to produce their own forms of scientific knowledge in order to help them to resolve problems and interact with phenomena that occur in their own context.

Historically, humanity has been exposed to different ways of scientific knowledge, which have been produced, accumulated, and diffused in different cultural contexts. This greater body of knowledge called ethnoscience is producing and documenting how humans interact within their own given contexts. Through studying the specific motivations that were often modified and altered with colonization or trade throughout history we gain a more nuanced understanding of what it is to be human (D'AMBROSIO, 2000).

The results of the many cross-cultural encounters across history further facilitate the interactions between those individuals whose objective ways to trade, conquer, dominate, or share experiences across seemingly different social, cultural, political, economic, and natural environments through cultural dynamism (D'AMBROSIO, 1990). Over time, the ethnosciences have evolved a deeper understanding and comprehension of science by developing a respect for cyclical relations that occur through dialogue, and which facilitate the establishment of symmetrical relations that permeate the encounters between these individuals.

Similarly, the ethnosciences are considered as a body of knowledge established as a system composed of explanations and different ways of doing (practices) and of knowing (theories) that characterize different cultures (D'AMBROSIO, 2001). Among these systems, the growing body of knowledge derived from qualitative and quantitative practices that document how humans count, weigh, measure, draw, infer, classify, and model is important for the ongoing development of the ethnomathematics program. Because it focuses more on the knowledge produced by the others, the ethnosciences are a multidisciplinary field of 
study that investigates the many roles that knowledge systems and their construction of reality.

Thus, the concept of the ethnosciences has influenced the development of an ethnomathematics program since it provided theoretical tools for the comprehension of interrelations between mathematical knowledge and the different cultural contexts, forms of cognition, and diverse social and spiritual practices. In this regard, the ethnosciences and ethnomathematics possess a symbiotic relation. Neither are new disciplines since their pedagogical implications take into account a variety of forces that have shaped diverse modes of thought in the sense of looking into the generation, organization (both intellectual and social) and diffusion of knowledge (D'AMBROSIO, 2001).

Because it developed out of the area of mathematics education as educators began to observe curious ways that communities used mathematics, the ethnomathematics program evolved independently from the ethnosciences. The ethnosciences maintained a strong relation with the natural sciences; ethnomathematics was connected to mathematics education and less with pure or academic mathematics. Since it focuses on the study of mathematical ideas, notions, procedures, practices produced and developed in the daily organization of the members of distinct cultural groups, ethnomathematics possesses characteristics that broaden the objectives of ethnoscience (D'AMBROSIO, 1993).

On the other hand, pedagogical implications of these two programs are related to factors that have come to influence, shape, and model the thinking of humanity. Both the ethnosciences and ethnomathematics can be considered as educational and research programs that are typically interdisciplinary, and that interrelate the results from cognition, epistemology, history, and education (ROSA, OREY, 2006). One objective of the theoretical character of the sciences seeks to explain and understand the structures and modes of social and cultural life is its approximation to the theoretical and practical aspects using ethnoscience. The main objective of this approach recognizes and promotes different ways of knowing and doing that are developed by different cultures.

As the ethnosciences are based on a scientific research paradigm that recognizes and values human cultural diversity, ethno-scientific research fields such ethno-x intersect with ethnomathematics as they study and appreciate everyday practices. The articulation between anthropology, theory, practice, an interest in cultural diversity, and the acceptance of innovative epistemological perspectives allows for the investigation of objects of study from the view of the members of distinct cultural groups. In this direction, studies related to ethnomathematics and the other ethno-xs such as ethnobiology and ethnobotany are also

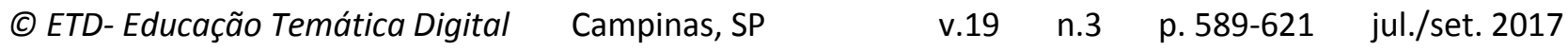


related to the anthropological, social, and cultural aspects developed by the members of these groups.

For example, one of the main objectives of ethnobiology and ethnoecology is related to the promotion of a theoretical foundation capable of integrating different branches of the natural and social sciences with other scientific systems (RIBEIRO, 1986). Philosophically, these objectives serve as a link between members of distinct cultural groups in an attempt to clarify comprehension and mutual respect among the members of these groups. Corroborating with this perspective, ethnomathematics aims to stimulate broader reflections about the nature of mathematical knowledge in the cognitive, historical, social, and cultural spheres. In this regard, this approach aims to understand the development of the practical as knowledge built over time by humanity (D'AMBROSIO, 2001).

The definition of term ethno-x follows the same principles as those that originated in other fields, namely ethnomathematics. They all apparently allow for the understanding that knowledge fields are conceived by humans acting in their own natural and cultural contexts. This encourages further study of the relations between these members with the social, cultural, economic, political, and natural environments. An important aspect of ethno-x knowledge areas such as ethnomathematics and ethnosciences is the constant concern to describe and present knowledge accumulated by members of distinct cultural groups from a cultural point of view.

In this approach, it is important for researchers, investigators, and ethnographers to catalog this knowledge by describing them in a way that the members of these groups understand, comprehend, and interpret them because they must be in agreement with the categories elaborated in accordance to the ethnosciences developed in each one of these cultures. For example, local communities such as indigenous, riverine, and artisanal fishers know where to find fish because they observed their behavior, the migration period, places where fish look for food and protect themselves from predators, and have accumulated information about the location of these resources and their availability.

Thus, they are able to elaborate planning and division of labor to avoid the disorderly and undue exploitation of the resources of their natural environment. They also developed elaborate management plans, ceremonies, and what we might call today projects to protect their natural resources available in that environment. This information could be harnessed to establish environmental management and conservation projects since the information generated by popular knowledge, transmitted by generations, allowed these communities to devise effective monitoring actions to prevent the shortage of these resources. For
(C) ETD-Educação Temática Digital
Campinas, SP
v.19
n.3
p. $589-621$
jul./set. 2017 
example, many Native American communities used controlled burning to encourage open forests and encourage better range and grassland to attract animals they hunted.

Popular knowledge indicates future sources of research by revealing the existing relations between nature, culture, and the environment. Communities can collaborate in providing information to assist in the elaboration of inventories of the species and listing the popular names of the species occurring in a particular region. Other information can also be added to the study such as the use of fish in home medicine, diet, and habitat of the fish species, as well as the amount to be fished to avoid the extinction of species that inhabit rivers and lakes of the natural environment in which these communities interrelate.

This exemplifies an approximation or initial link between ethnobiology, ethnoecology, and ethnomathematics through integrating the use of the scientific method to research the knowledge found in diverse communities. The connection between academic and local knowledge can be strengthened by knowledge gained and supported by cultural dynamics, which occurs when members of distinct cultural groups encounter, produce, generate, organize, disseminate, and institutionalize knowledge (ROSA; OREY, 2007).

Similarly, academic practices can also be considered modes of mathematical thinking defined by cultural background and the standards developed by members of distinct cultural groups and the institutions that practice them by translating this knowledge through an academic language to incorporate it as practices in everyday life.

\section{TRANDISCIPLINARITY OF ETHNOMATHEMATICS}

Over the past three decades, the theoretical bases for ethnomathematics have sought to ease sociocultural concerns as part of an examination of the cultural and socioeconomic influences on the processes related to teaching and learning mathematics. This includes knowledge of, as well as a commitment to challenging social injustice, and reflections upon the educational challenges related to identifying both obvious and subtle individual, institutional, and cultural actions that perpetuate social structures (ROSA; GAVARRETE, 2016). In this regard, ethnomathematics rose as a research program that:

(...) brings together and interrelates, results from the cognitive sciences, epistemology, history, sociology and education. An essential component is the recognition that science and mathematics are intellectual constructs of mankind in response to needs of survival and transcendence (D'AMBROSIO, 2001, p. 37). 
In this direction, ethnomathematics designates a transdisciplinary knowledge field that seeks to document, study, and value the ideas, procedures, and practices developed by members of distinct cultural groups, which are disseminated throughout history. These local practices of knowing and doing have emerged from a fusion of feedback and discourse between the natural, human, and social sciences (D'AMBROSIO, 2001).

\section{Social justice}

Many researchers in ethnomathematics would agree that an emphasis on education for social justice is paramount. It is increasingly necessary to empower students by teaching them about real-world issues and instill in them a desire to seek out and work towards their goals. Learning to develop and evaluate data over opinions is a powerful tool. Students who do not believe in, value, or recognize their own cultural roots can easily assimilate the dominant culture without critically reflecting on its values (D'AMBROSIO, 1999).

It is necessary to contextualize mathematics, as knowledge emerges from the context, needs, and expectations of communities that come to use it. This environment demonstrates how information may be meaningless, unless it is embedded in appropriate contextual understanding. Thus, social justice relies on the relevant political and cultural aspects of mathematics in order to mediate instruction and encourage exploration, interpretation, and reevaluation of how humanity has conceived its own forms of mathematics in diverse contexts.

However, it is important to emphasize that mathematical processes are not easily altered for most teaching social justice considerations. There are, of course, exceptions especially within the field of ethnomathematics that encourage the use of different methods of organizing mathematical ideas, procedures, practices, and problem solving, and which explore how members of different cultures organize and classify knowledge. When the focus of a study is the pedagogy of mathematics, the attention must be focused both around legitimizing student knowledge, originating from experiences built in their own contexts, as well as around pedagogical possibilities of how to work in conjunction with the learning processes that occur both outside and inside the school environment.

Indeed, discussions related to the educational aspects of ethnomathematics may help teachers establish cultural models of beliefs, thought, and behavior. This can be done by contemplating the potential of the pedagogical work that takes into account the sociocultural background of their students, as well as a more meaningful and empowering mathematical learning experiences. The suggestion of starting with a student's existing
(C) ETD- Educação Temática Digital
Campinas, SP
v.19 n.3
p. $589-621$
jul./set. 2017 
mathematical concepts is another way to provide a more critical examination of such concepts.

The consequence of this approach for teacher education is quite significant. It means that teachers must be supported and encouraged to know more about the mathematics and additional pedagogical competencies of their community in order to help their students undertake critical and reflective examinations of their own growing mathematical knowledge. In this regard, teaching is considered a higher order task that helps researchers, teachers, and students understand the connections between mathematics and culture.

Ethnomathematics emphasizes education for social justice, wherein it is necessary to empower individuals by teaching them about real-world issues and instills in them a desire to seek out and work towards this goal. Mathematics for social justice has to be equal for students from different cultural backgrounds. An important change in mathematics instruction needs to take place in order to accommodate ongoing social and cultural changes.

Therefore, teachers need the support, which enables them to create pedagogical actions related to their students. Individuals who do not believe in, or have not learned to value their mathematical background or their own cultural roots, can easily assimilate the dominant culture without critically reflecting on the values of a new or non-dominant culture. This essentially is a pedagogical colonization.

Participants in an ethnomathematics program learn to understand and accept the cultural roots of the dominated cultural group by coming to understand and value their mathematical ideas and practices. At the same time, they recognize the applications of academic mathematics and promote mathematical ideas and practices that were made by others. Certainly this program also supports the learning of mathematics of the dominant culture. This is because individuals from dominated cultural groups need to have equal access and be knowledgeable about the mathematics of the dominator (ROSA; OREY; 2003).

Ethnomathematics teaches us that mathematics is contextualized and grounded in the needs and expectations of the community that utilizes it. Teaching for social justice focuses on both the context and the understanding of mathematical and scientific ideas, practices, and processes, which may force confrontations in relation to assumptions about truth and knowledge, and which can easily be confused with the right and wrong of science and mathematics. 
Teaching for social justice with an ethnomathematical perspective reminds us that information may be meaningless unless is it embedded in an appropriate contextual understanding. Social justice relies on the relevant political and cultural aspects of mathematics in order to guide instruction. In other words, teaching for social justice encourages the exploration, interpretation, and reconsideration about what is understood about mathematics and science.

However, the processes of mathematics and science are not always amendable for teaching social justice considerations. There are, of course, exceptions especially within the field of ethnomathematics. This includes developing research agendas and sophisticated activities which explore different methods for organizing mathematical ideas and practices, and diverse forms of problem solving, and organizing explorations related to how different cultures organize and classify scientific knowledge.

\section{Trivium curriculum}

The Trivium Curriculum for Mathematics is composed of three central aspects: literacy, matheracy, and technoracy (D'AMBROSIO, 1999) and enables the development of school activities based on an ethnomathematics with a modelling foundation.

Literacy is the ability students have to process and use information present in their daily lives by applying reading, writing, representing, and calculating techniques, as well as using diverse media, and internet (D'AMBROSIO, 1999). From an ethnomathematical perspective, literacy is the integration of the cultural contexts of the school and the community through cultural dynamism, which allows students to exchange academic and local knowledge.

In a modelling perspective, teachers guide students to select a topic through dialogue and discussion. Themes are very general in nature, and allow students to engage in mathematical exploration and creativity. The implementation of mathematical modelling precedes the use of an ethnographic investigation of mathematical systems found in the school community (ROSA; OREY, 2015).

Matheracy is the ability students have to interpret and analyze signs and codes in order to propose models to find solutions for daily problems. It provides both symbolic and analytic instruments that help students develop creativity, and which can allow them to understand and solve new problems and situations (D'AMBROSIO, 1999). In an ethnomathematical perspective, matheracy is the domain of skills, strategies, and $\begin{array}{llllll}\text { (C) ETD- Educação Temática Digital Campinas, SP } & \text { v.19 } & \text { n.3 } & \text { p.589-621 } & \text { jul./set. } 2017\end{array}$ 
competencies that empower students to be aware of the way in which they explain their beliefs, traditions, myths, symbols, and scientific and mathematical knowledge.

In a modelling perspective, matheracy is the ability used to interpret, manipulate, and handle signs, symbols, and codes, as well as to propose the elaboration and use of mathematical models in everyday life. This approach allows students to have access to a diverse set of codes and symbols, essential in the decision making process for the elaboration of mathematical models (ROSA; OREY, 2015).

Technoracy, in order to assess the reasonableness of the results and their contextualization, is the ability students have to use and combine different technological instruments, which help them solve problems they encounter in everyday activities (D'AMBROSIO; D'AMBROSIO, 2013). From an ethnomathematical perspective, technoracy is as an important feature of scientific knowledge, as well as its reification as technological artifacts. It can manifest itself in technological tools that translate ways of dealing with natural, social, cultural, political, and economic environments.

Such environments facilitate the incorporation of diverse modes of explanation, belief, tradition, myth, and symbols in the development of mathematical knowledge. In the modelling process, technoracy is the incorporation and use of diverse tools that include calculators, computers, software, computational programs, and simulators. Frequently, the technological tools used in specific sociocultural contexts unleash the development and elaboration of mathematical models (ROSA; OREY, 2015).

Consequently, this curriculum model provides educators with a "critical way, with the communicative, analytical, and technological instruments necessary for life in the twenty-first century" (D'AMBROSIO; D'AMBROSIO, 2013, p. 22). The incorporation of the Trivium into classrooms implies a curricular reconceptualization in which ethnomathematics and mathematical modelling are tools for pedagogical action. It allows students and educators to move away from often emotion-based opinions, and towards more solid databased observations.

Ethnomathematics offers a broader view of mathematics, which embraces ideas, notions, procedures, processes, methods, and practices rooted in distinct cultural environments. This aspect can lead to increased evidence of cognitive processes, learning capabilities, and attitudes that direct learning processes in classrooms. In addition, by reflecting on the social and political dimensions of ethnomathematics, another important

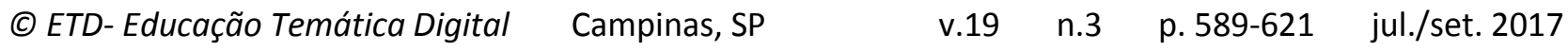


aspect of this program is the possibility for the development of innovative approaches for a dynamic and glocalized society. According to Rosa and Orey (2015), glocalization is the acceleration and intensification of interaction and integration among members of distinct cultural groups.

It also recognizes that such members develop unique techniques, methods, and explanations that enable alternative understanding, comprehension, new actions, and transformation of societal norms. At the same time, the theoretical basis of an ethnomathematics program is expanding as a valid alternative to traditional studies of the historical, philosophical, cognitive, and pedagogical aspects of mathematics. Thus, the research program for ethnomathematics is broadening its theoretical basis with the diversity of new investigations, as innovative approaches and frameworks are produced and implemented (ROSA, 2014).

It is necessary to discuss the interrelated transdisciplinary approaches in ethnomathematics programs such as its relation to social justice, human rights, indigenous education, professional contexts, game playing, urban and rural contexts, culturally relevant pedagogy, and teacher education programs. The Trivium Curriculum for Mathematics proposed by D'Ambrosio (1999) presents an important transdisciplinary ethnomathematics approach that needs more investigation in order to address its pedagogical purposes. The focus here is to develop the transdisciplinary interactions of the ethnomathematics program.

\section{FINAL CONSIDERATIONS}

There is a need to legitimize, systematize, formalize, and value traditional knowledge so that learners can move from the local to the global reach of ideas, notions, procedures, and practices developed locally and vice versa. There is a need to assist learners in connecting reality to the more abstract and powerful tools of mathematics. A base in the local forms of knowledge assists learners to focus on the study of, and the inclusion of, sociocultural aspects of phenomena that occur in specific cultural contexts (GUDYKUNST, 1997).

On the other hand, global knowledge focuses on the study of knowledge and practices that can be generalizable among members of distinct cultural groups since it is considered a universal phenomenon. Both local and global knowledge systems can be perceived as interrelated processes in the context of cultural diversity, which seeks to

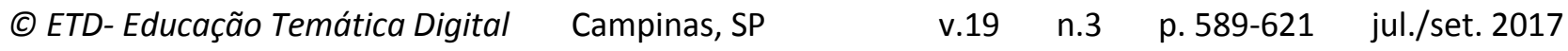


revitalize and enhance sociocultural identity of members of local cultural groups (GIDDENS, 2000).

Therefore, contemporary scenario for reflection on some aspects of ethnoscience and ethnomathematics, which despite being distinct knowledge fields, demonstrates the possibility for interactions and connections. According to this context, ethnomathematics can encourage a more active dialogue with the other ethno-x areas (COSTA, 2012). Because of the development of hybrid objects and subjects that easily integrate culture and knowledge, these two study fields often involve a set of relationships that cannot be relegated only to traditional study instituted by academic disciplines.

It is important to understand the interrelation between local practices and academic knowledge because distinct ways of doing (practices) and knowing (theories) that characterize given cultures are part of the shared knowledge of their members (D'AMBROSIO, 2001). As ethnomathematicians, the authors believe that mathematical knowledge is a set of ideas, procedures, techniques, and actions accumulated by the members of distinct cultural groups, composed of universal practices such as comparing, classifying, quantifying, measuring, explaining, generalizing, modelling, and evaluating that are inseparable and in permanent evolution.

Thus, it is necessary to discuss by means of a theoretical approach, as outlined above, how this knowledge can be both developed and used, by questioning the actual relevance of traditional disciplinary boundaries so that we can direct ourselves towards a broader understanding of the greater relations between members of distinct cultural groups and the overall social, cultural, economic, political, and natural environments that connect us all.

This context enabled the development of an ethno-methodological approach to show the interrelation of members of distinct cultural groups with diverse contexts. In this way, it is important that we strongly emphasize the concept of cultural dynamism, because it is a dynamic of interaction that is always present in encounters of individuals, and which makes it impossible to speak with precision about diverse cultures because they are in incessant transformation through the process of globalization (D'AMBROSIO, 2001).

This dynamism can be perceived as a theoretical and methodological study of the ways in which interrelations and interactions between the members of distinct cultural groups is triggered through the exchange of ideas, techniques, perspectives, explanations, and interpretations of everyday phenomena that occur in different contexts, and as a

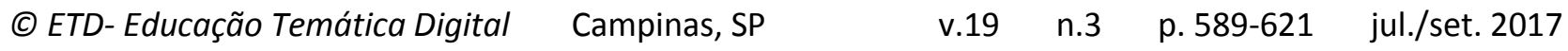


consequence, the generation of, new procedures, new practices, and eventually new results from these cultural encounters. Therefore, since knowledge does not fit into categories and segmentations (POSEY, 1987), there is a need to understand it holistically through the interrelation between the members of distinct cultural groups with their natural, cultural, political, economic, and social environments.

In this direction, from a sociocultural bias imbricated in the anthropological perspective and directed to the understanding of locally developed knowledge, distinct ethno-x, the ethnosciences, and ethnomathematics have the challenge of reducing the epistemological distances between the human, exact, and natural sciences. In this approach, it is necessary to break the boundaries between these study fields by means of the recognition of alternative systems of knowledge. For example, studies conducted by D’Ambrosio (1985), Villoro (1998), Arias-Schreiber (2001), Eglash at al. (2006), Rosa and Orey (2010) have addressed local knowledge systems through epistemological reflection, social and cultural questions, and juridical and environmental issues.

The members of distinct cultural groups act as social actors in order to favor the value of social diversity and cultural plurality (CUETO, 1995) of the sociocultural environment in which they are inserted. In this way, in order to symmetrically understand the relation between researchers, investigators, educators, and others, it is necessary to emphasize the importance of a scientific posture that enables the dialogue with local knowledge without the imposition of academic categories (POSEY, 1987). It is also important to emphasize here that his article sought to establish relations between knowledge fields of ethno- $\mathrm{x}^{7}$, for example, ethnobiology, ethnoecology, and the ethnosciences with ethnomathematics.

The establishment of these relations was based on the fact that the members of each cultural group construct their ethnosciences during the development of tools and instruments necessary to enable the process of reading their own world. This process enables the construction of knowledge so that the members of these groups can understand, comprehend, and explain by means of different readings, phenomena, and problem-situations they face in everyday life. Thus, ethnomathematics tries to study mathematics or mathematical ideas in its relations with the social and cultural lives (GERDES, 1997).

\footnotetext{
${ }^{7}$ In the term ethno- $x, x$ corresponds to the disciplinary suffix such as astronomy in ethnoastronomy, it can also be considered as an academic knowledge field (D'OLNE CAMPOS, 2002).

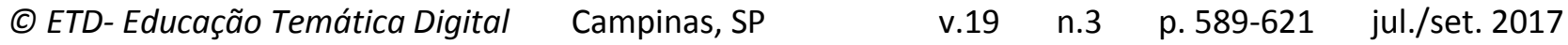


Since ethnomathematics was launched in the late 1970s, it was conceptualized by D'Ambrosio (1985) in a broad sense that approximates this program to the very notion of ethnoscience, which can be considered in an abstract way as a set of ethno-x. In regards to ethnomathematics, it is necessary to highlight that D'Olne Campos (2002) states that by using etymological arguments, D'Ambrosio (1985) seeks a general definition of ethnomathematics in order to identify it as an ethnoscience.

According to this context, ethnomathematics can be defined as an ethnoscience that studies the scientific and, by extension, technological phenomena, in direct relation with its social, economic, and cultural background (D'AMBROSIO 1993). We argue, therefore, that there is a significant dialogic interface between ethnomathematics, ethnoscience, and other ethno-x fields, which should lead to important interdisciplinary reflections as a consequence of diverse and distinct ways of reading the world.

There is a need to promote a synergy between knowledge developed locally with those used in the academy so that, through this cultural dynamism, local knowledge can interact with those consolidated in the academy by developing a dialogical relation between them. Thus, we have sought to present here, with this theoretical study, how we can all advance the possibility of a polysemic approach between different knowledge fields, which involve the breaking of some disciplinary and epistemological boundaries.

\section{REFERENCES}

ALCORN, Janis B. The scope and aims of ethnobotany in a developing world. In: SCHULTE, Richard Evans; REIS, Siri Von (Ed.). Ethnobotany: evolution of a discipline. Cambridge, England: Timber , 1995. p. 23-39.

ALMEIDA, Maria Zélia de. Plantas medicinais. Salvador, BA: EDUFBA, 2003.

ARAÚJO, Jussara de Loiola. Brazilian research on modelling in mathematics education. ZDM, v.42, n. 3, p. 337-348, 2010.

ARGUETA, Arturo. Epistemología e historia de las etnociencias. Dissertação de Mestrado em Ciências. Faculdade de Ciências. Cidade do México, México: UNAM, 1997.

ARIAS-SCHREIBER, Fidel Tubino. Interculturalizando el multiculturalismo. Encuentro Internacional sobre Interculturalidad. Barcelona, Espanha: Fundação CIDOB, 2001.

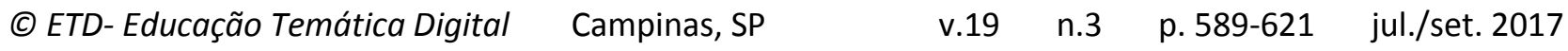


ARNOLD, Dean E. Ethnomineralogy of Ticul, Yucatan potters: etics and emics. American Antiquity, v. 36, n. 1, p. 20-40, 1971.

BARBOSA, Jonei Cerqueira. Mathematical modelling in classroom: a sociocritical and discursive perspective. ZDM, v. 38, n. 3, p. 293-301, 2006.

BARRAU, Jacques. A propos du concept d'ethnoscience. Ministère de la Culture. Direction du Patrimoine. Mission du Patrimoine Ethnologique. Actes du Séminaire de Sommières, 1984.

BASSANEZI, Rodney Carlos. Ensino-aprendizagem com modelagem matemática: uma nova estratégia. São Paulo, SP: Contexto, 2002.

BEGOSSI, Alpina. Ecologia humana: um enfoque das relações homem-ambiente. Interciência, v. 18, n.3, p. 121-132, 1993.

BOA, Eric. Non-wood forest products 17 - wild edible fungi: a global overview of their use and importance to people. Rome, Italy: FAO, 2004.

BROWN, Katrina. Climate anthropology: taking global warming to the people. Science, v. 283, p. 1440-1441, 1999.

CALDEIRA, Ademir Donizete. Etnomodelagem e suas relações com a educação matemática na infância. In BARBOSA, Jonei C., CALDEIRA, Ademir D., ARAÚJO, Jussara L. Modelagem matemática na educação matemática brasileira: pesquisas e práticas educacionais. Recife, PE: SBEM, 2007. p. 81-97.

CLEMENT, Daniel. The historical foundations of ethnobiology (1860-1899). Journal of Ethnobiology, v. 18, n. 2, p 161-187, 1998a.

CLEMENT, Daniel. Ethnobiology. Anthropologica, v. 40, n. 1, p. 7-34, 1998b.

CONKLIN, Herald Colyer. The relation of the Hanunóo culture to the plant world. Tese de Doutorado. New Haven, CT: Yale University, 1954.

COSTA-NETO, Eraldo Medeiros. Conhecimento e usos tradicionais de recursos faunísticos por uma comunidade Afro-brasileira. Resultados Preliminares. Interciência, v. 25, n. 9, p. 423-431, 2000.

CRUMP, Thomas. The anthropology of numbers. Cambridge, MA: Cambridge University, 1990.

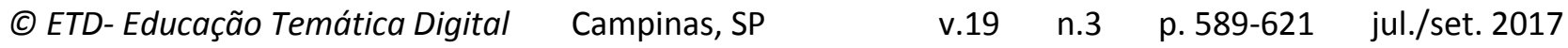


CUETO, Marcos. Saberes andinos: ciencia y tecnología en Bolivia, Ecuador y Perú. Lima, Peru: IEP, 1995.

D'AMBROSIO, Ubiratan. Ethnomathematics and its place in the history and pedagogy of Mathematics. For the Learning of Mathematics, v. 5, n. 1, p. 44-48, 1985.

D’AMBROSIO, Ubiratan. Etnomatemática: arte ou técnica de explicar e conhecer. São Paulo, SP: Ática, 1990.

D’AMBROSIO, Ubiratan. Etnomatemática: um programa. A Educação matemática em Revista, v. 1, n. 1, p. 5-11, 1993.

D'AMBROSIO, Ubiratan. Literacy, matheracy, and technoracy: a trivium for today. Mathematical thinking and learning, v. 1, n. 2, p. 131-153, 1999.

D'AMBROSIO, U. A historiographical proposal for non-Western mathematics. In SELIN, H. (Ed.) Mathematics across cultures: the history of non-Western mathematics. Dordrecht, Netherlands: Kluwer Academic, 2000. p. 79-92.

D'AMBROSIO, Ubiratan. Etnomatemática: elo entre as tradições a modernidade. Belo Horizonte, MG: Autêntica, 2001.

D'AMBROSIO, Ubiratan. Sociedade, cultura, matemática e seu ensino. Revista Educação e Pesquisa, v. 31, p. 99-120, 2005.

D'AMBROSIO, Ubiratan; D'AMBROSIO, BEATRIZ Silva. The role of ethnomathematics in curricular leadership in mathematics education. Journal of Mathematics Education at Teachers College, v. 4, 19-25, 2013.

D’OLNE CAMPOS, Márcio. Etnociência ou etnografia de saberes, técnicas e praticas? In AMOROSO, Maria Cristina de; MING, Lin Chau; SILVA, Sandra Maria Pereira da (Org.) Métodos de coleta eanálise de dados em etnobiologia, etnoecologia e disciplinas correlatadas. Rio Claro, SP: UNESP/CNPQ, 2002. p. 47-91.

EGLASH, Ron. African fractals: modern computing and indigenous design. New Jersey, NJ: Rutgers Univ., 1999.

EGLASH, Ron; BENNETT, Audrey; O'DONNELL, Casey; JENNINGS, Sybillyn; CINTORINO, Margaret. Culturally situated designed tools: ethnocomputing from field site to classroom. American Anthropologist, v. 108, n. 2, p. 347-362, 2006.

ELIZABETSKY, Elaine. Etnofarmacologia como ferramenta na busca de substâncias ativas. In: SIMÕES, Cláudia Maria Oliveira; SCHEMKEL, Eloir Paulo; GOSMANN, Grace (Ed.).
(C) ETD-Educação Temática Digital
Campinas, SP
v.19 $\quad$ n.3
p. $589-621$
jul./set. 2017 
Farmacognosia: da planta ao medicamento. Porto Alegre, RS - Florianópolis, SC: UFRGS/UFSC, 2000. p. 87-100.

FARIAS, Gilmar Beserra; ALVES, Ângelo Giuseppe Chaves. Aspectos históricos e conceituais da etnoornitologia. Biotemas, v. 20, n. 1, p. 91-100, 2006.

GERDES, Paulus. On culture, geometrical thinking and mathematics education. In POWELL, Arthur B.; FRANKENSTEIN, Marilyn (Eds.). Ethnomathematics: challenging Eurocentrism in mathematcs education. Albany, NY: State Univ. of New York, 1997. p. 223-247.

GIDDENS, Anthony. Runaway world: how globalization is reshaping our lives. New York: Routledge, 2000.

GUDYKUNST, William B. Cultural variability in communication: an introduction. Human Communication Research, v. 24, n. 4, p. 327-348, 1997.

HVIDING, Edvard. Between knowledge: pacific studies and academic disciplines. The Contemporary Pacific, v. 15, n. 1, p. 43-73, 2003.

IWANISZEWSKI, Stanislaw. Astronomy as a cultural system. Interdisciplinarni izsledvaniyja, v. 18. p. 282-288, 1991.

MARQUES, José Geraldo Wanderley. Pescando pescadores: etnoecologia abrangente no baixo São Francisco. São Paulo, SP: NUPAUB/USP, SP, 1995.

MORAN, Emilio F. Developing the Amazon. Bloomington. Indiana Univ., 1981.

NAZAREA, Virginia. Ethnoecology: situated knowledge/located lives. Tucson, AZ: Univ. of Arizona, 1999.

ONSTAD, Torgeir; KASANDA, Choshi D.; KAPENDA, Hileni M. Ethnomathematis: a link betweenan abstract school subject, local culture \& everyday experience. In CHILESA, Bagele, MAFELA, Lily; PREECE, Julia (Eds.). Educational research for sustainable development. Gaborone, Botswana: Lighthouse Publishers, 2003. p. 36-56.

POSEY, Darrell Addison. Introdução - etnobiologia: teoria e prática. In RIBEIRO, Darcy (Ed.). Suma Etnológica Brasileira. Petrópolis, RJ: Vozes: FINEP, 1987. p. 15-25.

RIBEIRO, Darcy. Suma etnológica brasileira. Petrópolis, RJ: Vozes-FINEP, 1986.

ROSA, Milton. From reality to mathematical modelling: a proposal for using ethnomathematical knowledge. Dissertação de Mestrado. College of Education. California State Univ., Sacramento, CA: CSUS, 2000.

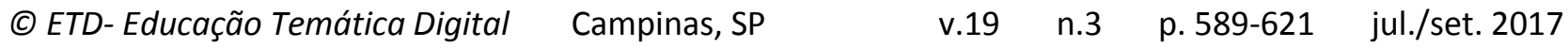


Rosa, Milton (2010). The perceptions of high school leaders about English language learners (ELL): the case of Mathematics. College of Education. Doctorate Dissertation. Sacramento, CA: CSUS.

ROSA, Milton. Explorando saberes e técnicas locais no contexto da etnomodelagem: destacando-se as abordagens êmica, ética e dialógica. Faculdade de Educação. Relatório de Pós-Doutorado. São Paulo, SP, Brasil: USP, 2014.

ROSA, Milton; GAVARRETE, María Elena (2016). Polysemic interactions between ethnomathematics and culturally relevant pedagogy. In ROSA, Milton; D'AMBROSIO, Ubiratan; OREY, Daniel Clark; SHIRLEY, Lawrence; ALANGUI, Wilfredo V.; PALHARES, Pedro; GAVARRETE, M. E. Current and future perspectives of ethnomathematics as a program. ICME13-Topical Surveys. London, England: SpringerOpen, 2016. p. 23-30.

ROSA, Milton; OREY, Daniel Clark Vinho e queijo: etnomatemática e modelagem! BOLEMA, v. 16, n. 20,p. 1-16, 2003.

ROSA, Milton; OREY, Daniel Clark. Raízes históricas do programa etnomatemática. Educação Matemática em Revista, v. 12, n. 18-19, p. 5-14, 2005.

ROSA, Milton; OREY, Daniel Clark. Abordagens atuais do programa etnomatemática: delinenando-se um caminho para a ação pedagógica. BOLEMA, v. 19, n. 26, p. 19-48, 2006.

ROSA, Milton; OREY, Daniel Clark. Cultural assertions and challenges towards pedagogical action of an ethnomathematics program. For the Learning of Mathematics, v. 27, n. 1, p. 10-16, 2007.

ROSA, Milton; OREY, Daniel Clark. Ethnomodelling: a pedagogical action for uncovering ethnomathematical practices. Journal of Mathematical Modelling and Application, v. 1, n. 3, p. 58-67, 2010.

ROSA, MILTON; OREY, DANIEL CLARK. Ethnomodelling as a methodology for ethnomathematics. In STILLMAN, Gloria A.; BROWN, Jill (ORGS.). Teaching mathematical modelling: connecting to research and practice. International perspectives on the teaching and learning of mathematical modelling. Dordrecht, The Netherlands: Springer. p. 77-88.

ROSA, Milton; OREY, OREY, Daniel Clark. A trivium curriculum for mathematics based on literacy, matheracy, and technoracy: an ethnomathematics perspective. ZDM, v. 47, n. 4, p. 587-598, 2015.

ROSA, Milton; OREY, Daniel Clark. Innovative approaches in ethnomathematics. In: ROSA, Milton; D'AMBROSIO, Ubiratan; OREY, Daniel Clark; SHIRLEY, Lawrence; ALANGUI, Wilfredo V.; PALHARES, Pedro; GAVARRETE, María Elena. Current and future perspectives of
(C) ETD-Educação Temática Digital
Campinas, SP
v.19
n.3
p. $589-621$
jul./set. 2017 
ethnomathematics as a program. ICME13-Topical Surveys. London, England: Springer Open, 2016. p. 18-23.

SANTOS-FITA, Dídac.; COSTA-NETO, Eraldo Medeiros. As interações entre os seres humanos e os animais: a contribuição da etnozoologia. BIOTEMAS, v. 20, n. 4, p. 99-110, 2007.

SCHULTES, Richard Evans; REIS, Siri Von. Ethnobotny: evolution of a discipline. Cambridge, England: Timber, 1995.

STURTEVANT, William C. Studies in ethnoscience. American Anthropologist, v. 66, n.30, p. 99-131, 1964.

TEDRE, Matti. Ethnocomputing: a multicultural view on computer science. Joensuu, Finland: Univ. of Joensuu, 2002.

TOLEDO, Vítor M. La apropiación campesina de la naturaleza: un análisis etnoecológico. Tese de doutorado em Ciências. Faculdade de Ciências. Cidade do México, México: UNAM, 1994.

VILLORO, Luís. Estado plural, pluralidad de culturas. Ciudad de México, México: PaidósUNAM, 1998.

VIZGIRDAS, Ray S.; REY-VIZGIRDAS, Edna. M. Wild plants of the Sierra Nevada. Reno, NV: Univ. of Nevada, 2006.

VOLTZ, Michel. The voltaic masks. The Drama Review, v. 26, n. 4, p. 38-45, 1982.

WASSON, Robert Gordon. The wondrous mushroom: mycolatry in Mesoamerica. New York, NY: McGraw-Hill, 1980.

WERHHART, Karl. R. Ethnohistory in Vienna. Vienna, Austria: Aachen Edition Herodot, 1987. WICKENS, Gerald E. What is economic botany? Economic Botany, v. 44, n. 1, p. 12-28, 1990. XOLOCOTZI, Efraím Hernández. La exploración etnobotánica y su metodología. Chapingo, México: Xolocotzia, 1985.

'The grammatical revision of this article was made by Linda Furuto from the University of Hawai'i at Mānoa.

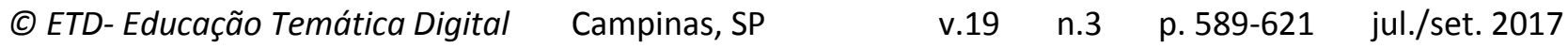

